\title{
Optimization of Keratinase Production Using Pseudomonas aeruginosa SU-1 Having Feather as
}

\section{Substrate}

\author{
Dhiva S ${ }^{1}$, Ranjith K R ${ }^{1}$, Prajisya $P^{1}$, Sona K P ${ }^{1}$, Narendrakumar G ${ }^{2}$, Prakash $P^{2}$, Emilin Renitta $R^{3}$, \\ Antony V Samrot 4* (D) \\ 1 Department of Microbiology, Sree Narayana College, Alathur, Palakkad, Kerala - 678682, India \\ 2 Department of Biotechnology, School of Bio and Chemical Engineering, Sathyabama Institute of Science and Technology, \\ Sholinganallur, Rajiv Gandhi Salai, Chennai, Tamil Nadu, 600119, India \\ 3 Department of Food Processing Technology, School of Agriculture and Biosciences, Karunya Institute of Science and \\ Technology, Karunya Nagar, Coimbatore - 641 114, India \\ 4 School of Biosciences, Faculty of Medicine, Biosciences and Nursing, MAHSA University, Jalan SP2, Bandar Saujana \\ Putra, 42610, Jenjarom, Selangor, Malaysia \\ * Correspondence: antonysamrot@gmail.com;
}

Scopus Author ID 36100751800

Received: 18.04.2020; Revised: 8.05.2020; Accepted: 10.05.2020; Published: 13.05.2020

\begin{abstract}
In this optimization study, Pseudomonas aeruginosa SU-1 was producing keratinase at optimal condition of 4 days, $\mathrm{pH}-7$ and temperature $37{ }^{\circ} \mathrm{C}$, where it was producing $23.7 \mathrm{U} / \mathrm{mL}$ After the one factor at a time, RSM was performed to understand the combination of the physical parameter that ends up for the maximum production of keratinase enzyme and the degradation percentage. The study involved in three variables ( $\mathrm{pH}(\mathrm{A})$, temperature(B) and Incubation Design $(\mathrm{C})$ ) in three ranges ($1,0,+1)$ using Box-Behnken Design (BBD). The results of the analysis of variance and regression analysis of the second order model showed that the factorial effect if the degradation. The optima of the variables $\mathrm{pH}-7$, temperature - 30 and incubation time -4 days. The isolated Pseudomonas species was subjected to feather degradation for 4 days and it was degrading $55.26 \%$. Keratinase was to be size of $56 \mathrm{KDa}$.
\end{abstract}

Keywords: Pseudomonas aeruginosa SU-1; Keratinase; Biomass; Feather Degradation.

(C) 2020 by the authors. This article is an open access article distributed under the terms and conditions of the Creative Commons Attribution (CC BY) license (https://creativecommons.org/licenses/by/4.0/).

\section{Introduction}

Chicken is one of the major sources of protein for non-vegetarian lovers. During the processing of chicken bulk quantities of feather gets discarded on the barren lands, roadsides, dump yards etc. In many of the developing countries like India it causes public disturbances like dust pollution, bad odour, files and rodents [1]. As the freshly disposed feather carries blood and few pieces of meat which facilitates the growth of various pathogenic microorganisms which emits various toxic gases such as nitrous oxide, ammonia and hydrogen sulphide, which is a major threat for life [2], Feather waste has also suggested being a cause of H5N1 virus outbreaks [3]. Over a period of time these wastes are burnt to reduce the solid waste by the local people which also leads to air pollution, water pollution, the introduction of contaminants in water bodies, creates health problems such as asthma, skin infections etc [48] These waste needs proper management to reduce such pollutions.

Since feather is made up of more than $90 \%$ of a protein called keratin which is composed of various aminoacids such as cystine, glutamine, lysine, proline, serine, threonine, 
and valine [9] and minerals like nitorgen $(\mathrm{N})$, phosphorus, potassium $(\mathrm{K})$, $\operatorname{calcium}(\mathrm{Ca})$, magnesium $(\mathrm{Mg})$, iron $(\mathrm{Fe})$, manganese $(\mathrm{Mn})$, zinc $(\mathrm{Zn})$, and copper $(\mathrm{Cu})$ [2] which is potentially good to be used in several fields [10]. Hydrolysed feather products can be used for the production of feed or fodder [11] good nitrogen fertilizer [12] for microbial growth [13].

Feathers can serve as important carbon and nitrogen sources for microbial culture [14]. Traditionally Feathers are treated by steam and chemicals to convert it into feather meal [15], but this method requires more energy and at the same time some of the amino acids may get destroyed during treatment [16]. Many microorganisms are capable of producing a variety of enzymes [17-19] including keratinolytic and proteolytic enzymes which are able to degrade feather keratin [20]. Researchers have isolated various keratinase producing microorganisms from different environments that are rich in keratin and which has been applied for degrading feather waste [21]. In the present study Pseudomonas aeruginosa SU-1 was used and optimal conditions such as time, temperature for enzyme production in the powdered feather as carbon source was determined and its effectiveness in full feather degradation was also analyzed.

\section{Materials and Methods}

\subsection{Isolation and Preparation of Inoculum.}

Soil sample isolates Pseudomonas aeruginosa SU-1 (Genbank accession number GU395985) was used for this study. All the chemicals used in this study were analytical grade and obtained from Qualigens Chemicals, India.

\subsection{Processing of feather.}

Broiler chicken feathers were collected from a nearby slaughterhouse in and around Alathur, Kerala, India. Bloodstains and other stains were washed off with tap water. The washed feathers were dried and then boiled in water at $100{ }^{\circ} \mathrm{C}$ for $30 \mathrm{~min}$. after that, it was dried inside hot air oven at $60{ }^{\circ} \mathrm{C}$. The dried feathers were blended into powder and sieved. The collected powder was used as source of keratin in this study.

\subsection{Optimization of growth on feather containing medium.}

\subsubsection{Incubation period optimization.}

Production media was prepared by dissolving $\mathrm{K}_{2} \mathrm{HPO}_{4}(0.04 \mathrm{~g})$, feather $(0.1 \mathrm{~g}), \mathrm{MgSO}_{4}$ $(0.2 \mathrm{~g}), \mathrm{K}_{2} \mathrm{PO}_{4}(0.5 \mathrm{~g}), \mathrm{pH}-7.0 \mathrm{in} 100 \mathrm{~mL}$ distilled water and sterilized under autoclave at $121^{0} \mathrm{C}$ for $15 \mathrm{~min} .24 \mathrm{~h}$ old culture was inoculated into the media incubated at $37^{\circ} \mathrm{C}$ for $24 \mathrm{~h}-96 \mathrm{~h}$. The enzyme activity was performed using keratinase assay at a different time interval to determine the maximum enzyme activity.

\subsection{2. $\mathrm{pH}$ optimization.}

At $30{ }^{\circ} \mathrm{C}$ temperature, the optimum $\mathrm{pH}$ was determined by incubating the chicken feature at different $\mathrm{pH}$ ranging from 4,5,6,7,8,9 and 10. The enzyme activity was performed using keratinase assay. 


\subsubsection{Temperature optimization.}

At optimized $\mathrm{pH}$ the optimum temperature was determined by incubating the chicken feature at a different temperature ranging from $20,25,30,35,40$ and $45^{\circ} \mathrm{C}$. the enzyme activity was performed using keratinase assay.

2.3.4. Response Surface Methodology Studies.

A RSM-BBD was conducted to analyzed the specific composition of physical variables required to enhance the production of keratinase enzyme from the chicken features by Pseudomonas aeruginosa SU-1. The statistical software package Design expert Version 7.0.0 was used for regression analysis to create different 3D graphs such as surface plot along with contour plot used to assess the statistical variables.

In the beginning of the statistical studies, the best minimal media combination was optimized for the production that conceived as production media. This media provides the basic requirement for the organism to grow and make mandatory of the supplemented compound to be used. The levels of three physical variables $(\mathrm{pH}$, Temperature and incubation time) were selected and each variable are coded A, B and C respectively at three level (-1,0 and 1) Table 1. In the analysis two responses were tested the degradation percentage $(\%)$ and the keratinase activity (IU/ml) (Table 2).

The mathematical connection of the independent parameters and the response was calculated by the second-order polynomial equation

$$
\mathrm{Y}=\eta_{0}+\mathrm{A} \eta_{1}+\mathrm{B} \eta_{2}+\mathrm{C} \eta_{1}+\mathrm{AB} \eta_{12}+\mathrm{BC} \eta_{23}+\mathrm{AC} \eta_{13}+\mathrm{A}^{2}+\mathrm{B}^{2}+\mathrm{C}^{2}
$$

in which $\mathrm{Y}$ is the response ( $\mathrm{Y} 1$ - Degradation percentage and $\mathrm{Y} 2$ - Keratinase production ) $\eta_{0}$ is the intercept, $\eta_{1}, \eta_{2}$, and $\eta_{3}$ are linear coefficient $\eta_{12}, \eta_{23}$ and $\eta_{13}$.are interaction coefficients.

\subsection{Enzyme assay.}

$5 \mathrm{mg}$ keratin azure powder was dissolved in $1 \mathrm{~mL} 50 \mathrm{mM}$ Tris $\mathrm{HCl}$ buffer ( $\mathrm{pH} 8.0)$. Now the suspension was added with $1 \mathrm{~mL}$ of crude enzyme (culture supernatant obtained after centrifugation at $10000 \mathrm{rpm}$ ) and kept at $50{ }^{\circ} \mathrm{c}$ for $30 \mathrm{~min}$. following that, $2 \mathrm{~mL} 0.4 \mathrm{M} \mathrm{TCA}$ was added to stop the reaction and centrifuged at $5000 \mathrm{rpm}$ for $40 \mathrm{~min}$, supernatant was read at 590nm. One unit (U) of enzyme activity was defined as described by Cai et al [22].

\subsection{Percentage of degradation of chicken feather.}

Percentage of feather degradation was found for the organism by sterilizing a feathers weighing $10 \mathrm{~g}$ and added to the aforementioned $100 \mathrm{~mL}$ media added with $10 \% 24 \mathrm{~h}$ old Pseudomonas aeruginosa SU-1. The set up was done with four steps and a control was also kept, where no organism was inoculated. Every two days gap, media from conical flask was removed and the feather was dried to know the degradation. Thus, it was done for 5 days and percentage degradation was determined.

\subsection{Characterization of enzyme.}

PAGE (polyacrylamide gel electrophoresis was carried out to identify the molecular weight of the enzyme). Glass plate was assembled space aid agar was used to seal the plate and the percentage separating gel was prepared with $30 \%$ of amide, $1.5 \mathrm{M}$ tris buffer, $10 \%$ SDS, $10 \%$ ammonium per sulfate (APS), TEMED and allowed to polymerization at room 
temperature for 2-5 minutes and prepared stacking gel with same chemicals except for $1.5 \mathrm{M}$ tris buffer and used $1 \mathrm{M}$ tris buffer and the comp was placed immediately and allowed to polymerization. After the comp was removed and the plate with gel was set to electrophoresis units and the SDS tank buffer was added immediately. Prepared sample $(10 \mu 1$ of sample and $10 \mu 1$ of $2 x$ SDS stain and incubated at $90^{\circ} \mathrm{c}$ for 10 minutes) was loaded $(10 \mu \mathrm{l})$ to the well along with marker. Run the gel with 50volt (v) of current for 4 hours, until the bromophenol blue reaches the bottom of the gel. The gel was suspended from the plate and stained with $0.5 \%$ commassie brilliant blue in water, acetic acid, methanol in the ratio 25:10:45 in the shaker 60$70 \mathrm{rpm}$ for overnight followed by destained (water :acetic acid : methanol-25:10:40) and the result was observed by using gel documentation and the molecular weight was identified.

\section{Results and Discussion}

Soil isolate Pseudomonas aeruginosa SU-1 used in this study was found to produce more enzyme quantity at $4^{\text {th }}$ day of incubation and the enzyme activity was $45 \mathrm{U} / \mathrm{mL}$ (Fig.1), where the optimal $\mathrm{pH}$ and temperature was found to be 7 and $30{ }^{\circ} \mathrm{C}$ respectively (Fig.2 and Fig.3). Very few works were reported on the ability of feather-degrading Gram negative bacteria [23-27]. Mohamad et al [24] reported that optimal production of keratinase by Pseudomonas sp LM19 at $\mathrm{pH} 8$ and $30{ }^{\circ} \mathrm{C}$ while using $1 \%$ feather as substrate. Pseudomonas sp., MS21 was producing maximum at $37^{\circ} \mathrm{C}$ and $\mathrm{pH} 8.0$ [23].

The results obtained in terms of degradation percentage by suggesting to the experiments executed conferring to the BBD are given in Table 3. In the regression analysis, coefficient of determination $\left(\mathrm{R}^{2}\right)$ was computed as 0.980099 for Degradation percentage production (model summary in Table 4), indicating that the statistical model can explain $98.0 \%$ of variability in the response. The adjusted $\mathrm{R}^{2}$ value corrects the $\mathrm{R}^{2}$ value for the sample size and for the number of terms in the model. The value of the adjusted determination coefficient (Adj $\mathrm{R}^{2}=0.954512$ ) is also very high, sponsoring higher importance of the model. $\mathrm{R} 2$ value calculated as 0.983097 for keratinase production indicating the statistical model can be $98.3 \%$. The adjusted R2 0.961365 correlates with the R2 value. The predicted R2 value 0.970545 correlates along with the other values.

The empirical relationship between degradation percentage (Y1) and keratinase production (Y2) and the three test factors in coded units obtained by using the formulae

Keratinase activity $=21.8+1.362 \mathrm{~A}-0.925 \mathrm{~B}+0.3625 \mathrm{C}-3.55 \mathrm{AB}+1.325 \mathrm{AC}-4.55$ BC - 8.3625 $\mathrm{A}^{2}-7.0875 \mathrm{~B}^{2}-5.6125 \mathrm{C}^{2}$

Degradation $\%=50.187+3.347 \mathrm{~A}-1.849 \mathrm{~B}+0.577 \mathrm{C}-7.733 \mathrm{AB}+2.938 \mathrm{AC}-$ $10.38 \mathrm{BC}-18.675 \mathrm{~A}^{2}-15.883 \mathrm{~B}^{2}-12.812 \mathrm{C}^{2}$

The regression analysis results in the developed $\mathrm{x}$ of surface plots that reveal the relationship of the variables with respect to the response. The response (\%) of degradation and (IU/mL) of keratinase from chicken feather for different test parameters can also be predicted from the respective surface plots, as shown in Fig. 4 and Fig.5. Each surface plot represents an infinite number of permutation and combination of two test parameters at their corresponding zero level. These plots demonstrate that the degradation and production of keratinase were dependent on the linear effects of $\mathrm{pH}$, temperature and incubation time. The results of physical condition optimization studies from Pseudomonas aeruginosa SU-1 used in the present studies were good and compared well with those of studies of other microorganisms. Thus, the condition was optimized with RSM shows at $\mathrm{pH} 7$, Temperature $30{ }^{0} \mathrm{C}$ and incubation of 4 days showed maximum productivity and degradation of the chicken feather powder. 
In this study, it was found that P.aeruginosa SU-1 was degrading $55.26 \%$ of the feather (Fig. 6 and 7). Approximately 86\% feather degradation was achieved at optimal condition by Pseudomonas sp LM19 [24]. In our study, the organism was degrading up to $55 \%$ in the optimal medium condition in 4 - 5 days. B. licheniformis BBE11-1 and Stenotrophomonas maltophilia BBE11-1 were able to degrade $35.4 \%$ and $22.8 \%$ respectively in $96 \mathrm{~h}$. while they were allowed to degrade in a coculture system, it was reaching to $55.2 \%$ which might the higher keratinase/protease activities [28]. The organism used in this study was producing enzyme of size $56 \mathrm{KDa}$ (Fig.8), where Han et al [29] reported P.aeruginosa C11 to produce $33 \mathrm{KDa}$ sized keratinase and Tork et al [23] found Pseudomonas sp., MS21 to produce 30 KDa keratinase. The enzyme produced here might be a dimeric enzyme. These keratin derived hydrolysates have been reported to have more application including phyto stimulant and biofertilizer [30 33]. Microbial derived products and their uses are well defined already [34,35].

Table 1. Experimental Range and Levels of three Independent Variables Used in response surface methodology in Terms of low and high, actual and coded factors for Optimization of physical parameters for the Degradation and Keratinase Production as response.

\begin{tabular}{|c|c|c|c|c|c|c|c|}
\hline \multirow{2}{*}{ Factor } & \multirow{2}{*}{ Name } & \multirow{2}{*}{ Units } & \multicolumn{2}{|c|}{ Low } & \multicolumn{2}{|c|}{ High } & \multirow{2}{*}{ Std. Dev. } \\
\hline & & & Coded & Actual & Coded & Actual & \\
\hline A & $\mathrm{pH}$ & & -1 & 5 & 1 & 9 & 1.371989 \\
\hline $\mathrm{B}$ & Temperature & $\mathrm{C}$ & -1 & 25 & 1 & 35 & 3.429972 \\
\hline $\mathrm{C}$ & Incubation time & days & -1 & 2 & 1 & 6 & 1.371989 \\
\hline Response & Name & Units & \multicolumn{2}{|l|}{ Minimum } & $\mathrm{um}$ & \multicolumn{2}{|c|}{ Mean } \\
\hline Y1 & Degradation \% & $\%$ & \multicolumn{2}{|c|}{12.5} & \multicolumn{2}{|l|}{94.5} & 47.7 \\
\hline Y2 & Keratinase activity & $\mathrm{IU} / \mathrm{ml}$ & \multicolumn{2}{|l|}{2.5} & 23.7 & & 1.88824 \\
\hline
\end{tabular}

Table 2. Design Matrix of BBD and Observed Results for Degration precentage and Keratinase Production.

\begin{tabular}{|c|c|c|c|c|c|c|c|}
\hline \multirow{3}{*}{ Run } & \multirow{3}{*}{$\begin{array}{l}\text { Factor 1 } \\
\mathrm{A}: \mathrm{pH}\end{array}$} & \multirow{3}{*}{$\begin{array}{l}\text { Factor } 2 \\
\text { B:Temperature } \\
\text { C } \\
\end{array}$} & \multirow{3}{*}{$\begin{array}{l}\text { Factor } 3 \\
\text { C:Incubation time } \\
\text { Days } \\
\end{array}$} & \multicolumn{4}{|c|}{ Response } \\
\hline & & & & \multicolumn{2}{|c|}{ Degradation \% } & \multicolumn{2}{|c|}{ Keratinase activity } \\
\hline & & & & $\%$ & & $\mathrm{IU} / \mathrm{ml}$ & \\
\hline 1 & 7 & 35 & 2 & 52.4 & 30.64 & 12.4 & 12.4 \\
\hline 2 & 9 & 25 & 4 & 50.4 & 29.47 & 12.3 & 12.2 \\
\hline 3 & 7 & 30 & 4 & 82.6 & 48.30 & 22.3 & 21.8 \\
\hline 4 & 7 & 30 & 4 & 85.6 & 50.06 & 21.4 & 21.8 \\
\hline 5 & 7 & 30 & 4 & 94.5 & 55.26 & 23.7 & 21.8 \\
\hline 6 & 7 & 30 & 4 & 91.6 & 53.57 & 22.9 & 21.8 \\
\hline 7 & 5 & 30 & 6 & 22.7 & 13.27 & 5.4 & 5.5 \\
\hline 8 & 7 & 35 & 6 & 17.9 & 10.47 & 4.2 & 4.0 \\
\hline 9 & 5 & 35 & 4 & 29.5 & 17.25 & 7.5 & 7.6 \\
\hline 10 & 7 & 25 & 6 & 56.6 & 33.10 & 14.9 & 14.9 \\
\hline 11 & 7 & 25 & 2 & 20.1 & 11.75 & 4.9 & 5.1 \\
\hline 12 & 9 & 30 & 6 & 44.2 & 25.85 & 10.8 & 10.9 \\
\hline 13 & 5 & 30 & 2 & 29.8 & 17.43 & 7.5 & 7.4 \\
\hline 14 & 7 & 30 & 4 & 74.8 & 43.74 & 18.7 & 21.8 \\
\hline 15 & 9 & 30 & 2 & 31.2 & 18.25 & 7.6 & 7.5 \\
\hline 16 & 5 & 25 & 4 & 12.5 & 7.31 & 2.5 & 2.4 \\
\hline 17 & 9 & 35 & 4 & 14.5 & 8.48 & 3.1 & 3.2 \\
\hline
\end{tabular}

Table 3. Model Coefficients Estimated by Multiple Linear Regression for the Keratinase production.

\begin{tabular}{l|r|r|r|r|l|l}
\hline \multicolumn{1}{c|}{ Source } & $\begin{array}{c}\text { Sum of } \\
\text { Squares }\end{array}$ & df & $\begin{array}{c}\text { Mean } \\
\text { Square }\end{array}$ & $\begin{array}{c}\text { F } \\
\text { Value }\end{array}$ & $\begin{array}{c}\text { p-value } \\
\text { Prob }>\text { F }\end{array}$ & \\
\hline Model & 874.0301 & 9 & 97.11446 & 45.23715 & $<0.0001$ & Significant \\
\hline A-pH & 14.85125 & 1 & 14.85125 & 6.917901 & 0.0339 & \\
\hline B-Temperature & 6.845 & 1 & 6.845 & 3.188488 & 0.1173 & \\
\hline C-Incubation time & 1.05125 & 1 & 1.05125 & 0.489686 & 0.5066 & \\
\hline $\mathrm{AB}$ & 50.41 & 1 & 50.41 & 23.48162 & 0.0019 & \\
\hline $\mathrm{AC}$ & 7.0225 & 1 & 7.0225 & 3.27117 & 0.1134 & \\
\hline $\mathrm{BC}$ & 82.81 & 1 & 82.81 & 38.57395 & 0.0004 & \\
\hline $\mathrm{A}^{\wedge} 2$ & 294.448 & 1 & 294.448 & 137.1576 & $<0.0001$ & \\
\hline $\mathrm{B}^{\wedge} 2$ & 211.5059 & 1 & 211.5059 & 98.52214 & $<0.0001$ & \\
\hline $\mathrm{C}^{\wedge} 2$ & 132.6322 & 1 & 132.6322 & 61.78178 & 0.0001 & \\
\hline Residual & 15.0275 & 7 & 2.146786 & & & \\
\hline
\end{tabular}


https://doi.org/10.33263/BRIAC105.65406549

\begin{tabular}{|c|c|c|c|c|c|c|}
\hline Lack of Fit & 0.1875 & 3 & 0.0625 & 0.016846 & 0.9965 & not significant \\
\hline Pure Error & 14.84 & 4 & 3.71 & & & \\
\hline Cor Total & 889.0576 & 16 & & & & \\
\hline Std. Dev. & & 1.465191 & R-Squared & & & 0.983097 \\
\hline Mean & & 11.88824 & Adj R-Squared & & & 0.961365 \\
\hline C.V. \% & & 12.32472 & Pred R-Square & & & 0.970545 \\
\hline PRESS & & 26.1875 & Adeq Precision & & & 17.29699 \\
\hline
\end{tabular}

Table 4. Model Coefficients Estimated by Multiple Linear Regression for the degradation precentage.

\begin{tabular}{|c|c|c|c|c|c|c|}
\hline Source & $\begin{array}{l}\text { Sum of } \\
\text { Squares }\end{array}$ & $\mathrm{df}$ & $\begin{array}{l}\text { Mean } \\
\text { Square }\end{array}$ & $\begin{array}{l}\mathrm{F} \\
\text { Value }\end{array}$ & $\begin{array}{l}\text { p-value } \\
\text { Prob > F }\end{array}$ & \\
\hline Model & 4413.344 & 9 & 490.3716 & 38.30426 & $<0.0001$ & significant \\
\hline A-pH & 89.67033 & 1 & 89.67033 & 7.004394 & 0.0331 & \\
\hline B-Temperature & 27.36269 & 1 & 27.36269 & 2.137375 & 0.1871 & \\
\hline C-Incubation time & 2.667915 & 1 & 2.667915 & 0.208398 & 0.6619 & \\
\hline $\mathrm{AB}$ & 239.254 & 1 & 239.254 & 18.68878 & 0.0035 & \\
\hline $\mathrm{AC}$ & 34.5414 & 1 & 34.5414 & 2.698123 & 0.1445 & \\
\hline $\mathrm{BC}$ & 430.9873 & 1 & 430.9873 & 33.6656 & 0.0007 & \\
\hline $\mathrm{A}^{\wedge} 2$ & 1468.514 & 1 & 1468.514 & 114.7096 & $<0.0001$ & \\
\hline $\mathrm{B}^{\wedge} 2$ & 1062.194 & 1 & 1062.194 & 82.97085 & $<0.0001$ & \\
\hline $\mathrm{C}^{\wedge} 2$ & 691.2401 & 1 & 691.2401 & 53.99465 & 0.0002 & \\
\hline Residual & 89.61407 & 7 & 12.80201 & & & \\
\hline Lack of Fit & 7.329606 & 3 & 2.443202 & 0.118769 & 0.9444 & not significant \\
\hline Pure Error & 82.28446 & 4 & 20.57112 & & & \\
\hline Cor Total & 4502.958 & 16 & & & & \\
\hline Std. Dev. & & 3.57799 & \multicolumn{2}{|l|}{ R-Squared } & & 0.980099 \\
\hline Mean & & 27.89474 & \multicolumn{2}{|c|}{ Adj R-Squared } & & 0.954512 \\
\hline C.V. \% & & 12.82676 & \multicolumn{2}{|c|}{ Pred R-Squared } & & 0.945404 \\
\hline PRESS & & 245.8432 & \multicolumn{2}{|c|}{ Adeq Precision } & & 15.95767 \\
\hline
\end{tabular}

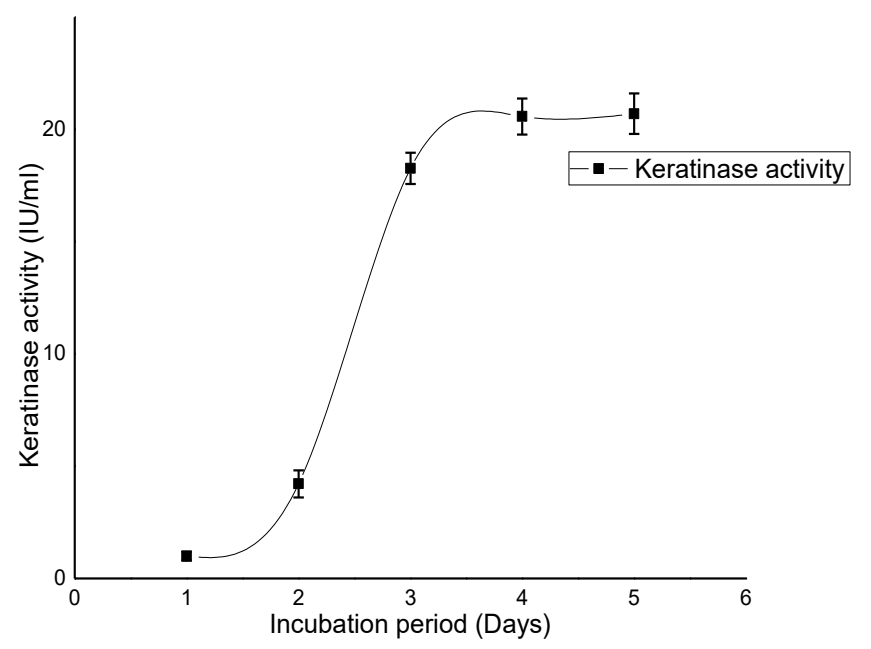

Figure 1. Keratinase activity of P.aeruginosa at different incubation time.

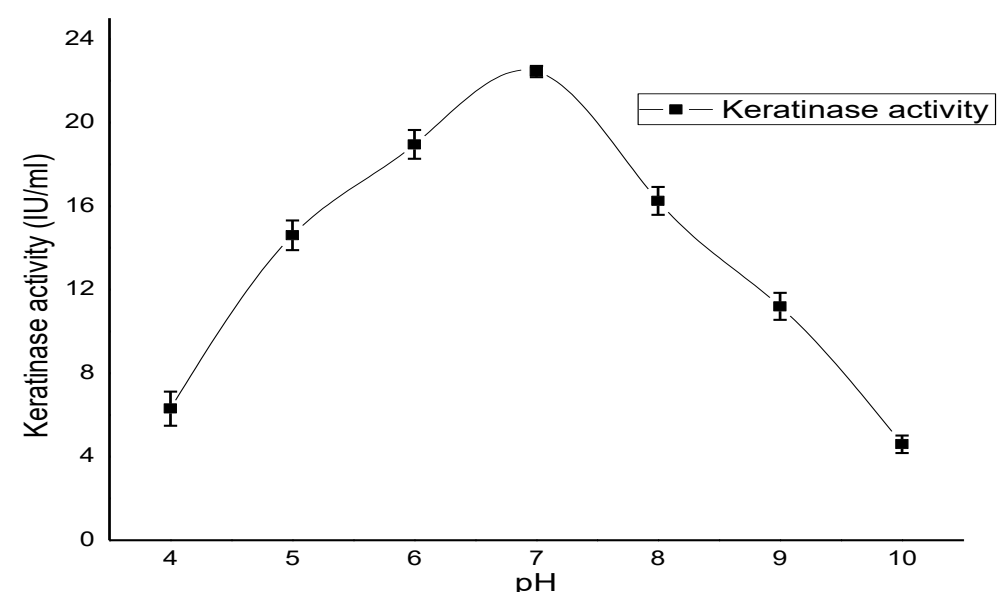

Figure 2. Keratinase activity of P.aeruginosa at different $\mathrm{pH}$. 


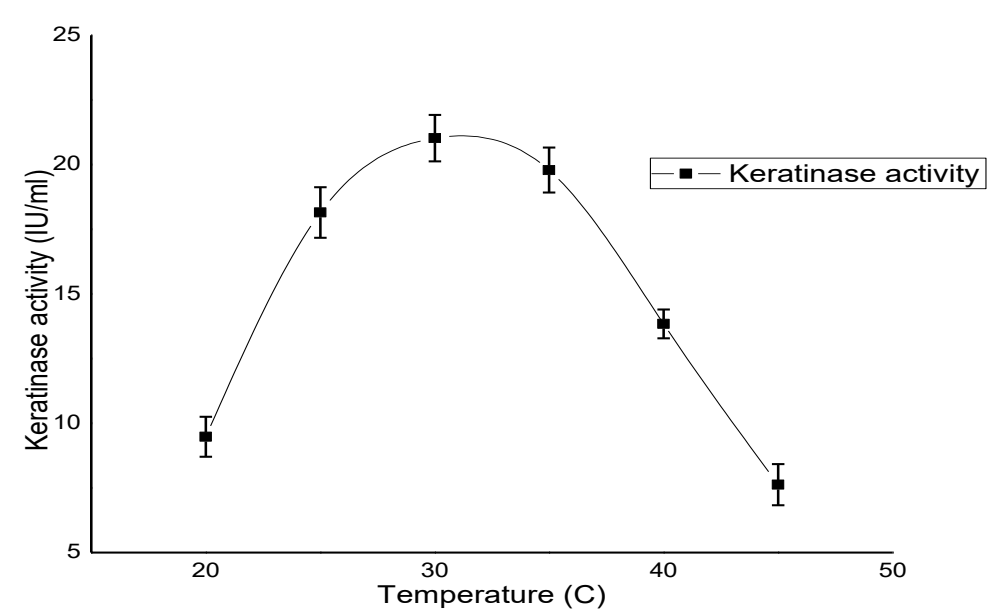

Figure 3. Keratinase activity of P.aeruginosa at different temperature.
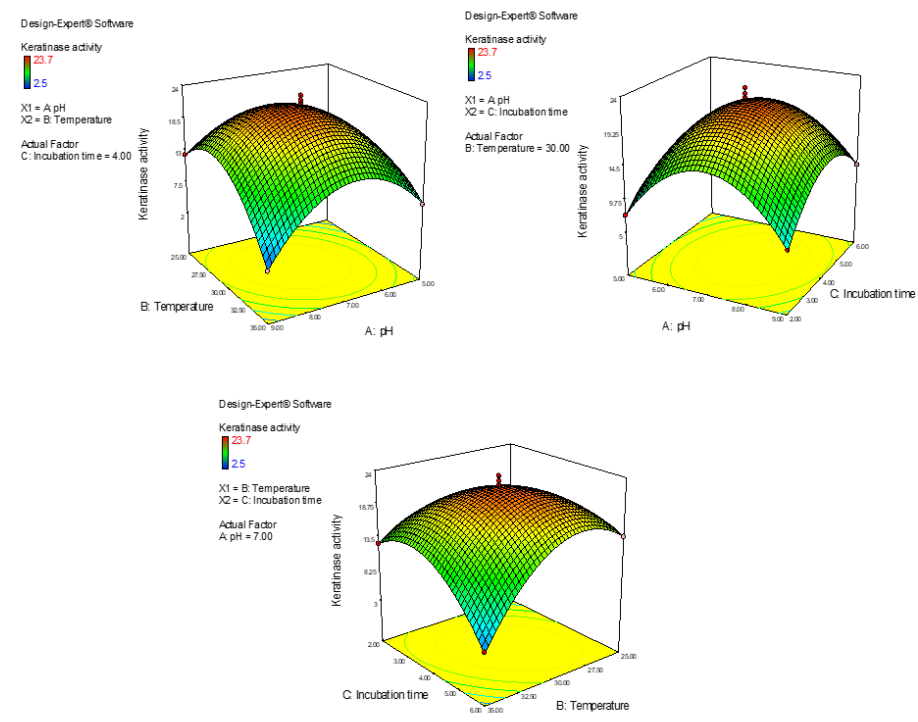

Figure 4. Surface plots of keratinase production optimization studies. (A) Effect of $\mathrm{pH}$ and temperature and their interaction on keratinase production; (B) effect of $\mathrm{pH}$ and incubation period and their interaction on keratinase production; $(\mathbf{C})$ effect of Temperature and incubation period and their interaction on keratinase production.
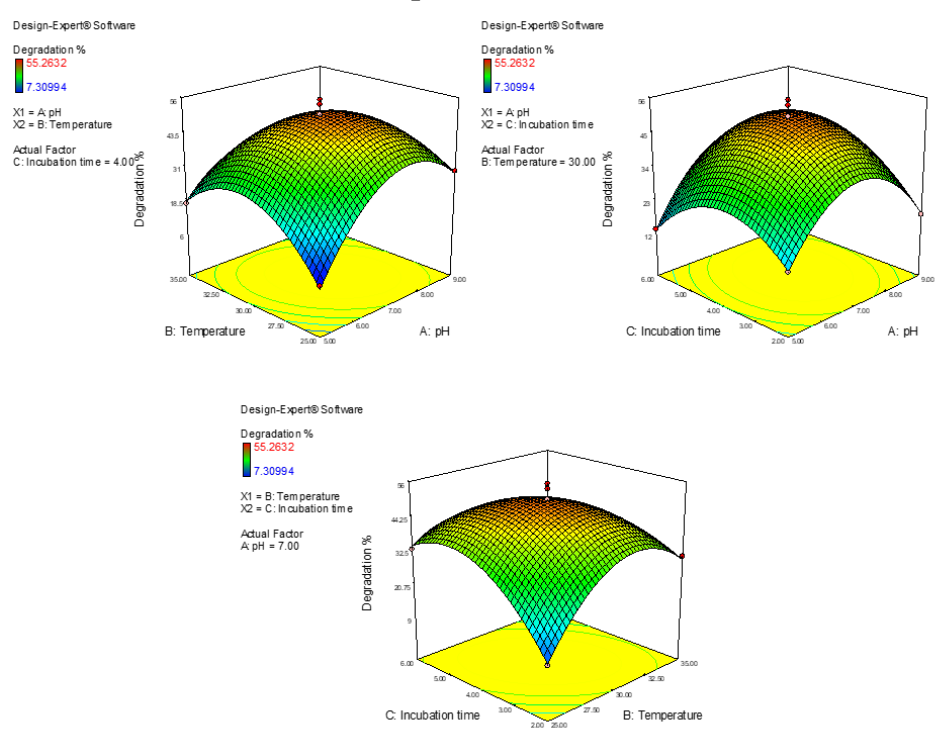

Figure 5. Surface plots of keratinase production optimization studies. (A) Effect of $\mathrm{pH}$ and temperature and their interaction on keratinase production; (B) effect of $\mathrm{pH}$ and incubation period and their interaction on keratinase production; (C) effect of Temperature and incubation period and their interaction on keratinase production. 

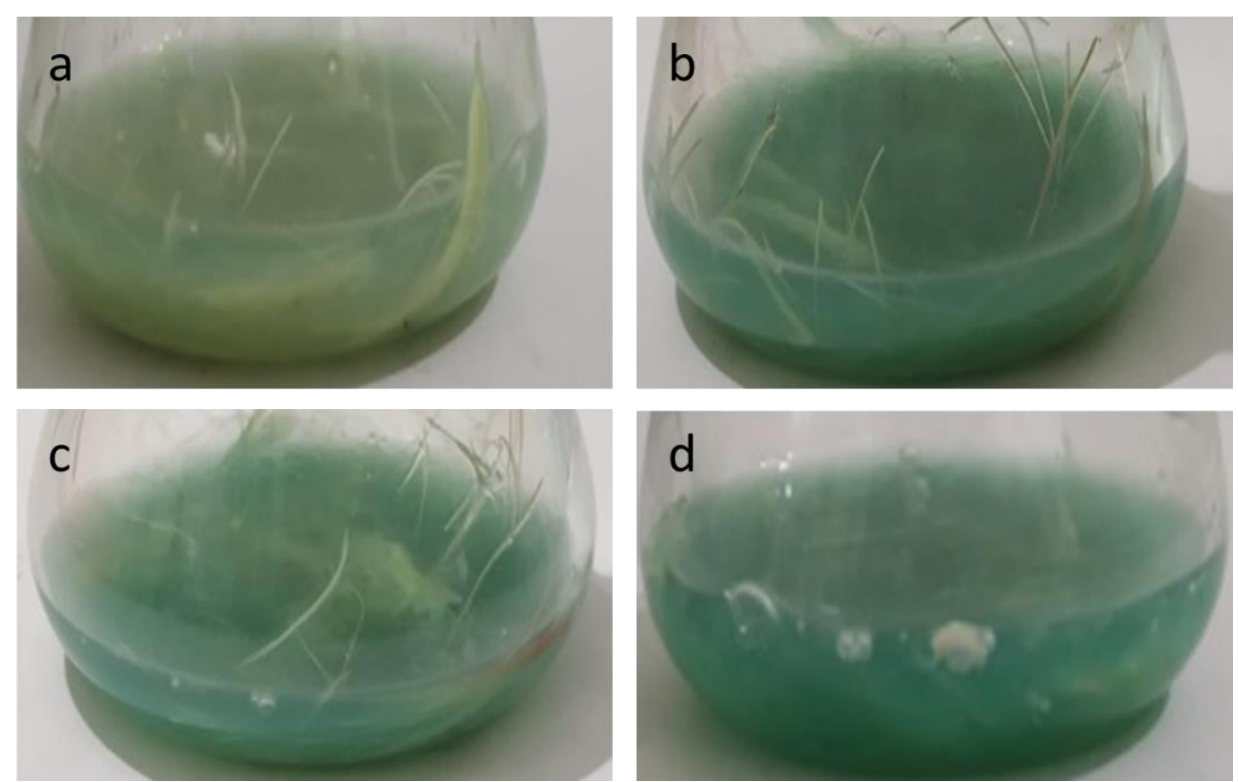

Figure 6. Percentage degradation of feather by Pseudomonas aeruginosa SU-1 a) Day - 2, b) Day - 3, c) Day 4 and d) Day -5.

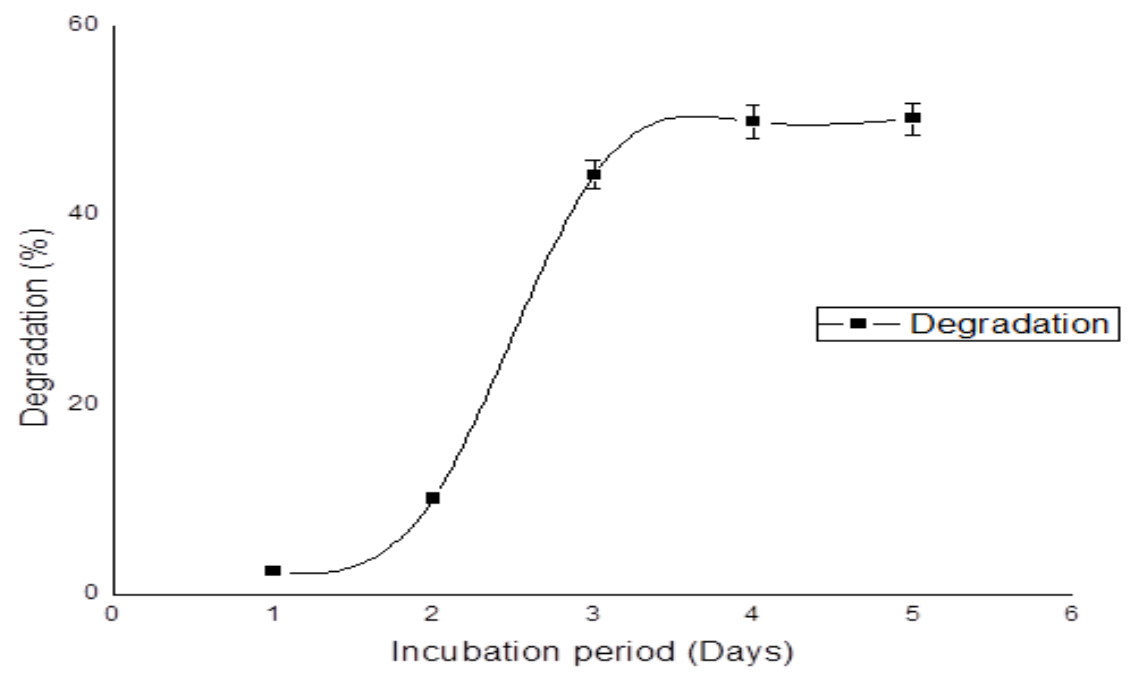

Figure 7. Feather degradation by Pseudomonas aeruginosa SU-1 a) Day 2 b) Day 4 c) Day 6 and d) Day 8.

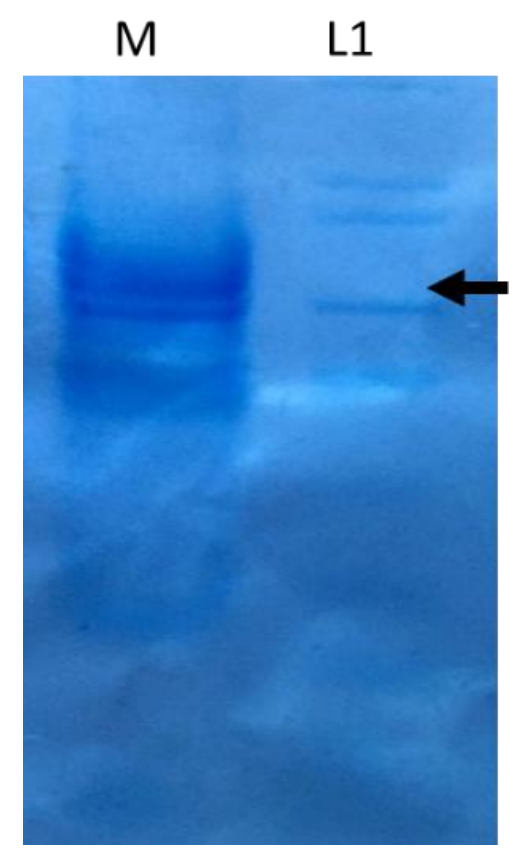

Figure 8. SDS - PAGE analysis of keratinase M - Marker, L1 - Lane 1 Keratinase enzyme (56 KDa). 


\section{Conclusions}

In this study, soil isolates Pseudomonas aeruginosa SU-1 was used to produce keratinase having feather powder as source, where the optimal condition was determined as $\mathrm{pH}-7$, temperature $-30{ }^{\circ} \mathrm{C}$ and incubation time -4 days. The organism was degrading $55 \%$ of the feather in 4 days. Keratinase produced by the organism was about the size of 56KDa.

\section{Funding}

This research received no external funding.

\section{Acknowledgments}

This research has no ackwnoledgments.

\section{Conflicts of Interest}

The authors declare no conflict of interest.

\section{References}

1. Gerber, P.; Opio, C.; Steinfeld, H. Poultry production and the environment-a review. 2012.

2. Verma, A.; Singh, H.; Anwar, S.; Chattopadhyay, A. Microbial keratinases: industrial enzymes with waste management potential. Crit. Rev. Biotechnol. 2017, 37, 476-491, https://doi.org/10.1080/07388551.2016.1185388.

3. Agrahari, S.; Wadhwa, N. Degradation of chicken feather a poultry waste product by keratinolytic bacteria isolated from dumping site at Ghazipur poultry processing plant. Int J Poult Sci. 2010, 9, 482-489, https://doi.org/10.3923/ijps.2010.482.489.

4. Kang, D.; Herschend, J., Al-Soud, W.A.; Mortensen, M.S.; Gonzalo, M.; Jacquiod, S.; Sørensen, S.J. Enrichment and characterization of an environmental microbial consortium displaying efficient keratinolytic activity. Bioresour. Technol. 2018, 270, 303-310, https://doi.org/10.1016/j.biortech.2018.09.006.

5. Bhavya, K.S.; Raji, P.; Selvarani, A.J.; Samrot, A.V.; Javad, P.T.M.; Appalaraju, V.V.S.S. Leather processing, its effects on environment and alternatives of chrome tanning. International Journal of Advanced Research In Engineering And Technology (IJARET). 2019, 10, 69-79, https://doi.org/10.34218/IJARET.10.6.2019.009.

6. Samrot, A.V.; Sahithya, C.S.; Selvarani, A.J.; Pachiyappan, S.; Kumar. S.S. Surface-Engineered SuperParamagnetic Iron Oxide Nanoparticles For Chromium Removal. Int. J. Nano Med. 2019, 2019, 81058119, https://doi.org/10.2147/IJN.S214236.

7. Raji, P.; Samrot, A.V.; Bhavya, K.S.; Sharan, M.; Priya, S.; Paulraj, P. Greener Approach for Leather Tanning Using Less Chrome with Plant Tannins and Tannins Mediated Nanoparticles. J Clust Sci. 2019, 30, 1533-1543, https://doi.org/10.1007/s10876-019-01597-6.

8. Samrot, A.V.; Shobana, N.; Sruthi, D.P.; Sahithya, C.S. Utilization of chitosan coated superparamagnetic iron oxide nanoparticles for chromium removal. Appl. Water Sci. 2018, 8, 192, https://doi.org/10.1007/s13201-018-0841-4.

9. Tesfaye, T.; Sithole, B.; Ramjugernath, D. Valorisation of chicken feathers: a review on recycling and recovery route - current status and future prospects. Clean Technol. Environ. Policy. 2017, 19, 2363-2378, https://doi.org/10.1007/s10098-017-1443-9.

10. Sharma, S.; Gupta, A. Sustainable management of keratin waste biomass: applications and future perspectives. Braz. Arch. Biol. Technol. 2016, 59, e16150684, https://doi.org/10.1590/1678-43242016150684.

11. Onifade, A.A.; Al-Sane, N.A.; Al-Musallam, A.A.; Al-Zarban, S. A review: potentials for biotechnological applications of keratin-degrading microorganisms and their enzymes for nutritional improvement of feathers and other keratins as livestock feed resources. Bioresour. Technol. 1998, 66, 1-11, https://doi.org/10.1016/S0960-8524(98)00033-9.

12. Joardar. J.C.; Rahman, M.M. Poultry feather waste management and effects on plant growth. International Journal of Recycling of Organic Waste in Agriculture 2018, 7, 183-188, https://doi.org/10.1007/s40093018-0204-z. 
13. Williams, C.M.; Shih, J.C.H. Enumeration of some microbial groups in thermophilic poultry waste digesters and enrichment of a feather-degrading culture. J. Appl. Bacteriol. 1989, 67, 25-35, https://doi.org/10.1111/j.1365-2672.1989.tb04951.x.

14. Li, Q. Progress in Microbial Degradation of Feather Waste. Front. Microbiol. 2019, 10, https://doi.org/10.3389/fmicb.2019.02717.

15. Kim, W.K.; Patterson, P.H. Nutritional value of enzyme- or sodium hydroxide-treated feathers from dead hens. Poult. Sci. 2000, 79, 528-534, https://doi.org/10.1093/ps/79.4.528.

16. Papadopoulos, M.C. Effect of processing on high-protein feedstuffs: a review. Biol. Wastes. 1989, 29, 123138, https://doi.org/10.1016/0269-7483(89)90092-X.

17. Samrot, A.V.; Vijay, S.A. A-Amylase Activity Of Wild And Mutant Strains Of Bacillus Sp. The Internet Journal of Microbiology. 2009, 6.

18. Chandramohan, M.; Yee, C.Y.; Beatrice, P.H.K.; Ponnaiah, P.; Narendrakumar, G.; Samrot, A.V. Production, characterization and optimization of fibrinolytic protease from Bacillus pseudomycoides strain MA02 isolated from poultry slaughter house soils. Biocatal. Agric. Biotechnol. 2019, 22, https://doi.org/10.1016/j.bcab.2019.101371.

19. Samrot AV, Shobana N, Kumar SS and Narendrakumar G. Production, optimization and characterisation of chitosanase of bacillus sp and its applications in nanotechnology. 2019. J. Clus. Sci. 2019, 30, 607-620, https://doi.org/10.1007/s10876-019-01520-z.

20. Williams, C. M.; Lee, C. G.; Garlich, J. D.; Shih, J. C. H. Evaluation of a bacterial feather fermentation product, feather-lysate, as a feed protein. Poult. Sci. 1991, 70, 85-94, https://doi.org/10.3382/ps.0700085.

21. Chaturvedi, V.; Bhange, K.; Bhatt, R.; Verma, P. Production of kertinases using chicken feathers as substrate by a novel multifunctional strain of Pseudomonas stutzeri and its dehairing application. Biocatal. Agric. Biotechnol. 2014. 3, 167-174, https://doi.org/10.1016/j.bcab.2013.08.005.

22. Cai, C.; Lou, B.; Zheng, X. Keratinase production and keratin degradation by a mutant strain of Bacillus subtilis. J Zhejiang Univ Sci B. 2008, 9, 60-67, https://doi.org/10.1631/jzus.B061620.

23. Tork, S.; Aly, M.M.; Nawar, L. Biochemical and molecular characterization of a new local keratinase producing Pseudomonas sp., MS21. Asian J. Biotechnol. 2010, 2, 1-12, https://doi.org/10.3923/ajbkr.2010.1.13.

24. Mohamad, N.; Phang, L.; Abd-Aziz, S. Optimization of metallo-keratinase production by Pseudomonas sp. LM19 as a potential enzyme for feather waste conversion. Biocatalysis and Biotransformation. 2017, 2017, 1-10, https://doi.org/10.1080/10242422.2017.1280031.

25. Brandelli, A.; Daroit, D.J.; Riffel, A. Biochemical features of microbial keratinases and their production and applications. Appl. Microbiol. Biotechnol. 2010, 85, 1735-1750, https://doi.org/10.1007/s00253-0092398-5.

26. Bach, E.; Daroit, D.J.; Corre^a, A.P.F.; Brandelli, A. Production and properties of keratinolytic proteases from three novel Gram-negative feather-degrading bacteria isolated from Brazilian soils. Biodegradation. 2011, 22, 1191-1201, https://doi.org/10.1007/s10532-011-9474-0.

27. Jeong, J.H.; Park, K.H.; Oh, D.J; Hwang, D.Y., Kim, H.S., Lee, C.Y., Son, H.J. Keratinolytic enzymemediated biodegradation of recalcitrant feather by a newly isolated Xanthomonas sp. P5. Polym. Degrad. Stab. 2010, 95, 1969-1977, https://doi.org/10.1016/j.polymdegradstab.2010.07.020.

28. Peng, Z.; Mao, X.; Zhang, J.; Du, G.; Chen, J. Effective biodegradation of chicken feather waste by cocultivation of keratinase producing strains. Microb. Cell. Fact. 2019, 18, https://doi.org/10.1186/s12934019-1134-9.

29. Han, M.; Luo, W.; Gu, Q.; Yu, X. Isolation and characterization of a keratinolytic protease from a featherdegrading bacterium Pseudomonas aeruginosa C11. Afr. J. Microbiol. Res. 2012, 6, 2211-2221..

30. Kshetri, P.1, Roy, S.S.; Sharma, S.K.; Singh, T.S.; Ansari, M.A.; Sailo, B.; Singh, S.; Prakash, N. Feather degrading, phytostimulating, and biocontrol potential of native actinobacteria from North Eastern Indian Himalayan Region. J Basic Microbiol. 2018, 58, 730-738. https://doi.org/10.1002/jobm.201800169.

31. Li, Q. Progress in Microbial Degradation of Feather Waste. Front. Microbiol 2019, 05, https://doi.org/10.3389/fmicb.2019.02717.

32. Tamreihao, K.; Mukherjee, S.; Khunjamayum, R.; Devi, L.J.; Asem, R.S.; Ningthoujam, D.S. Feather degradation by keratinolytic bacteria and biofertilizing potential for sustainable agricultural production. Journal of Basic Microbiology 2019, 59, 4-13, https://doi.org/10.1002/jobm.201800434.

33. Oluwaseun, A.C., Phazang, P.; Sarin, N.B. Production of ecofriendly biofertilizers produced from crude and immobilized enzymes from Bacillus subtilis $\mathrm{CH} 008$ and their effect on the growth of Solanum lycopersicum. Plant Archives. 2018, 18, 1455-1462.

34. Halevas, E.G., Pantazaki, A.A. Advances in the optimized synthesis of biotechnologically valuable products from bioengineered microbial cell factories. Biointerface Research in Applied Chemistry 2018, $8(4), 3463-3482$.

35. Fwazi, S., Ali, A. Performance of cellulose acetate propionate in polycaprolactone and starch composites: biodegradation and water resistance properties. Biointerface Research in Applied Chemistry. 2020, 10(3), 5382 - 5386, https://doi.org/10.33263/BRIAC103.382386. 